\title{
ПРОБЛЕМЫ РАЗУМНОСТИ СРОКА УГОЛОВНОГО СУДОПРОИЗВОДСТВА НА СТАДИИ ПРОИЗВОДСТВА ВВИДУ НОВЫХ ИЛИ ВНОВЬ ОТКРЫВШИХСЯ ОБСТОЯТЕЛЬСТВ В СВЕТЕ РЕШЕНИЙ КОНСТИТУЦИОННОГО СУДА РОССИЙСКОЙ ФЕДЕРАЦИИ И ЕВРОПЕЙСКОГО СУДА ПО ПРАВАМ ЧЕЛОВЕКА
}

Аннотация: Зачастую участникам уголовного процесса, а также иным лицам, чьи права и интересы затрагиваются в ходе разбирательства, приходится сталкиваться с длительностью процессуальных процедур, что, безусловно, влечет за собой нарушение их прав. Проблемы определения срока уголовного производства являются предметом исследования в уголовном процессе и в конституционном праве России. В статье поднимаются проблемы неустановленности и неопределенности срока производства по уголовному делу ввиду новых и вновь открывшихся обстоятельств. Для преодоления вопроса неопределенности срока производства авторы анализируют подходы копределению «разумности» срока, сформулированные в судебной практике Конституционного Суда Российской Федерации и Европейского Суда по правам человека. В исследовании использованы как общие, так специальные методы: анализ, обобщение, сравнительно-правовой, логико-юридическийметоды. В статье изложены предложения по вопросуустранения проблемы определения неопределенности срока производства по уголовному делу ввиду новых и вновь открывшихся обстоятельств. С учетом правовых позиций Конституционного Суда РФ и Европейского Суда по правам человека о «разумности» срока судебного разбирательства авторы предлагают при определении срока во время производства ввиду новых или вновь открывшихся обстоятельств разумно было бы ориентироваться на общий срок производства предварительного следствия (ст. 162 УПК РФ). Началом исчисления такого срока следует считать день возбуждения производства, окончанием - день составления прокурором заключения и направления его с материалами расследования в суд или день вынесения постановления о прекращении производства. В статье изложены и другие предложения по совериенствованию уголовно-процессуального законодательства РФ.

Abstract: The parties involved in the criminal procedure, as well as other persons whose rights or interests are being affected by the investigation are often faced with a lengthy process, which inevitably carries violations of their rights. The problems of defining the term of a criminal procedure are the subject of the research in criminal process and constitutional law of the Russian Federation. This article raises questions of uncertainty and indefiniteness of the term of procedure of criminal cases due to new and newly discovered circumstances. In order to resolve the issue of indefiniteness of the duration of the procedure the authors analyze approaches to the definition of "reasonableness" of the length of time formulated within court proceedings of the Constitutional Court of the Russian Federation and the European Court for Human Rights. Taking into account the legal positions of the Constitutional Court of the Russian Federation and the European Court for Human Rights on the "reasonableness" of the duration of court proceedings the authors propose using the general term of proceedings of preliminary investigation (article 162 of the Criminal Procedure Code of the Russian Federation). This term should commence on the day of the beginning of investigation and end on the day that the prosecutor compiles his findings and submits them to the court, or on the day of announcing the drop of investigation. Ключевые слова: Разумный срок разбирательства, уголовное судопроизводство, Конституционный Суд РФ, ЕСПЧ, новые обстоятельства, вновь открывшиеся обстоятельства, судебная защита прав, Европейская конвениия, справедливое судебное разбирательство, судебная практика.

Keywords: Reasonable term of investigation, criminal procedure, Constitutional Court of the Russian Federation, European Court for Human Rights, new evidence, legal protection of rights, European Convention, fair trial, court proceedings.

П роблемы определения срока уголовного производства являются предметом междисциплинарных исследований: им уделяют внимание в уголовном процессе и в конституционном праве. Определяющую роль для выработки решений этой проблемы являются подходы, выработанные в практике Конституционного Суда РФ и Европейского Суда по правам человека.

В настоящее время вопрос соблюдения разумных сроков в рамках производства по новым делам и по вновь открывшимся обстоятельствам является достаточно актуальным. Зачастую участникам процесса, а также иным лицам, чьи права и интересы затрагиваются в ходе разбирательства, приходится сталкиваться с длительностью процессуальных процедур, что, безусловно, влечет за собой нарушение их прав.
Глава 49 УПК РФ «Возобновление производства по уголовному делу ввиду новых или вновь открывшихся обстоятельств», которая предусматривает особенности данного вида производства, никак не определяет процессуальные сроки данных видов производств. Таким образом, законодатель отсылает нас к общим положениям уголовно-процессуального законодательства.

Согласно ст. 6.1 УПК РФ «уголовное судопроизводство осуществляется в разумный срок», а именно «при определении разумного срока уголовного судопроизводства, который включает в себя период с момента начала осуществления уголовного преследования до момента прекращения уголовного преследования или вынесения обвинительного приговора, учитываются такие обстоятельства, как правовая и фактическая сложность уголовного дела, поведение участников 
DOI: $10.7256 / 1811-9018.2014 .12 .13260$

При цитировании этой статьи сноска на dоі обязательна

Судебная власть

уголовного судопроизводства, достаточность и эффективность действий $<\ldots>$ руководителя следственного органа, следователя, <..> производимых в целях своевременного осуществления уголовного преследования или рассмотрения уголовного дела, и общая продолжительность уголовного судопроизводства».

Статья 5 УПК РФ, закрепляющая основные понятия, используемые в Кодексе, определяет «уголовное судопроизводство - досудебное и судебное производство по уголовному делу», «досудебное производство - уголовное судопроизводство с момента получения сообщения о преступлении до направления прокурором уголовного дела в суд для рассмотрения его по существу»; «судебное разбирательство» - судебное заседание судов первой, второй, кассационной и надзорной инстанций.

Таким образом, производство ввиду новых или по вновь открывшимся обстоятельствам, не является уголовным судопроизводством в понимании действующего российского уголовно-процессуального закона.

Так, разумность - это во многом оценочное понятие, отражающее некое усреднённое требование, означающее логичность, целесообразность. Очевидно, что понятие «разумность» законодатель, как правило, должен использовать в тех случаях, когда невозможно установить абсолютные сроки, предвидеть какие-либо конкретные препятствия для соблюдения процессуального срока.

В целом, критерии «разумности срока» носят исключительно оценочный характер разумности срока, что, в свою очередь означает, что правоприменитель вынужден использовать абсолютно субъективный механизм, который не устанавливает никаких пределов и превышения разумности сроков производства по делу и зачастую провоцирует лишь новые судебные разбирательства в части нарушения прав и свобод человека и гражданина.

Например, при анализе производства ввиду новых обстоятельств по делу о незаконном сбыте наркотических веществ производство без принятия окончательного решения длилось (и продолжает длиться) более трех лет:

07.10.2011 г. и.о. прокурора Центрального района г. Калининграда было вынесено постановление о возбуждении производства ввиду новых обстоятельств.

20.09.2012 г. (спустя почти 11 месяцев!) ст. следователь следственного отдела по Центральному району СУ СК России по Калининградской области приняла дело к производству.

14.03.2014 г. потерпевший направил заявление в следственный отдел по Центральному району г. Калининграда, в котором просил сообщить о ходе расследования и о результатах проведения следственных действий, на основании уже удовлетворенных в октябре 2012 года следователем ходатайств.

19.03.2014 г. потерпевший получил ответ из следственного отдела по Центральному району СУ СК России по Калининградской области, в котором сообщается, что расследование ввиду новых обстоятельств производится в соответствии со ст. 415 УПК РФ, и что уголовно-процессуальным законодательством не предусмотрена обязанность следователя информировать заинтересованное лицо о ходе расследования и объеме проведенной работы.

Фактически с июля 2012 года не было произведено ни одного действия направленного на установления истины по данному уголовному делу.
С момента принятия уголовного дела по вновь открывшемся обстоятельствам к производству ст. следователем следственного отдела по Центральному району СУ СК России по Калининградской области прошло $\mathbf{3}$ года, что выходит за рамки понимания «разумного срока».

С 2012 года по настоящее время также было вынесено 3 судебных постановления, подтверждающих факт бездействия следователя по данному делу и обязывающих вышестоящих руководителей исправить все допущенные нарушения.

В июне и июле 2014 году при попытке установить сроки производства по делу в суде и привести расследование к окончанию, судом в установлении сроков было отказано в первой и в апелляционной инстанции в связи с тем, что требование об установлении сроков не основано на законе'

Процессуальные возможности по обжалованию явного бездействия органов и должностных лиц явно ограничены виду сложившейся правовой ситуации.

Важно также, что законодатель установил возможность взыскания компенсации за нарушение права на судопроизводство в разумный срок, и данная возможность формально не применима к рассматриваемым нами производствам, а возможно применение общих положений о гражданско-правовой ответственности государственных органов, должностных лиц ${ }^{2}$. Такую рестрикционную позицию занимает и Верховный Суд Российской Федерации ${ }^{3}$.

Полагаем, что законодатель не зря отразил положения о необходимости осуществления судопроизводства «в сроки, установленные настоящим Кодексом» именно в части 2 ст. 6.1. УПК РФ («Разумный срок уголовного производства»), тем самым как бы указывая правоприменителю, что установленность, определенность срока является непременной и важнейшей характеристикой понятия «разумность».

Не следует также забывать о положениях части 3 ст. 6.1. УПК РФ: «При определении разумного срока уголовного судопроизводства, который включает в себя период с момента начала осуществления уголовного преследования до момента прекращения уголовного преследования (курсив авторов) или вынесения обвинительного приговора». В то же время та же статья 5 УПК РФ довольно обще трактует уголовное преследование - процессуальная деятельность, осуществляемая стороной обвинения в целях изобличения подозреваемого, обвиняемого в совершении преступления. Такой подход

\footnotetext{
${ }^{1}$ Архив Центрального районного суда г. Калининграда.

2 Определение Конституционного Суда Российской Федерации от 03.04.2014 г. № 687-О «Об отказе в принятии к рассмотрению жалобы гражданина Лунина Валерия Васильевича на нарушение его конституционных прав статьями 1 и 3 Федерального закона «О компенсации за нарушение права на судопроизводство в разумный срок или права на исполнение судебного акта в.4, 244.6 и 244.8 Гражданского процессуального кодекса Российской Федерации». [Электрон.ресурс]. Доступ из справ. - правовой системы «КонсультантПлюс».

${ }^{3}$ Определение Верховного Суда Российской Федерации от 11.10.2011 г. № КАС11-528: «При этом суд обоснованно не согласился с доводом заявителя о том, что общая продолжительность судопроизводства по уголовному делу составила 8 лет 5 месяцев, так как в соответствии с нормами процессуального закона, а также Закона о компенсации период судопроизводства в надзорной инстанции не подлежит оценке с точки зрения разумности» [Электрон.ресурс]. Доступ из справ. правовой системы «КонсультантПлюс».
} 
DOI: $10.7256 / 1811-9018.2014 .12 .13260$

При цитировании этой статьи сноска на dоі обязательна

\section{Право и политика $12(180) \cdot 2014$}

может привести к более широкому, неформализованному толкованию уголовного производства. Ведь в расширенном смысле возобновление производства по уголовному делу ввиду новых или вновь открывшихся обстоятельств, вне всякого сомнения, направлено на изобличение лиц, виновных в преступлениях, а значит, такая стадия относится к уголовному судопроизводства в понимании части 3 ст. 6.1 УПК РФ.

Такое расширительное толкование возможно в гражданском судопроизводстве. Там оно неожиданно нашло свое отражение в совместном Постановлении Пленума Верховного Суда РФ и Высшего Арбитражного суда РФ: «Период производства по пересмотру вступивших в законную силу судебных актов по гражданскому делу в порядке надзора или по вновь открывшимся обстоятельствам включается в общую продолжительность судопроизводства в случае, если по результатам пересмотра судом принято определение (постановление) на основании статьи 390 или части 3 статьи 397 ГПК РФ», то есть производство по вновь открывшимся обстоятельствам стало результативным и послужило предпосылкой для вынесения постановления судом кассационной инстанции либо судебного определения по специальным правилам ${ }^{4}$.

Некоторые авторы также относят рассматриваемые нами производства к стадиям уголовного судопроизводства: «Речь идет об обеспечении прав потерпевших от преступлений на различных стадиях уголовного судопроизводства (возбуждения уголовного дела; предварительного расследования; судебного разбирательства; постановления и исполнения приговора; апелляционного, кассационного и надзорного производства; производства в виду новых и вновь открывшихся обстоятельств) ${ }^{5}$ ».

В то же время, другие специалисты полагают, что эти производства не могут быть полноценными стадиями как с точки зрения национального, так и международного права: «Однако $<\ldots>$ отсутствуют конкретные указания о том, как следует учитывать срок производства по уголовному делу < .. > по вновь открывшимся обстоятельствам (<..> проведения проверки или расследования новых или вновь открывшихся обстоятельств). < ..> при подсчете срока, оцениваемого с точки зрения разумности, в него не должны включаться процедуры, связанные с рассмотрением вопроса о возобновлении судебного разбирательства. Если же вступившие в законную силу судебные решения были отменены и производство по уголовному делу возобновлено, то новое судебное разбирательство может рассматриваться в аспекте определения разумного срока ${ }^{6}$.

${ }^{4}$ П. 44 Постановление Пленума Верховного Суда Российской Феде-
рации №30, Пленума Высшего Арбитражного Суда Российской Фе-
дерации №64 от 23.12 .2010 г. «О некоторых вопросах, возникших при
рассмотрении дел о присуждении компенсации за нарушение права на
судопроизводство в разумный срок или права на исполнение судебного
акта в разумный срок» [Электрон.ресурс]. Доступ из справ. - правовой
системы «КонсультантПлюс».

${ }^{5}$ Международно-правовые стандарты в уголовной юстиции Российской Федерации: научно-практическое пособие / С.П. Андрусенко, Н.А. Голованова, А.А. Гравина; отв. ред. В.П. Кашепов. М.: Институт законодательства и сравнительного правоведения при Правительстве РФ, Анкил, 2012. [Электрон.ресурс]. Доступ из справ. - правовой системы «КонсультантПлюс».

${ }^{6}$ Кондрат И.Н. Международные корни уголовно-процессуального принципа «разумный срок уголовного судопроизводства» // Российская юстиция. - 2012. - №12. - С. 29 - 32.
Применительно к постановлению судом оправдательного приговора либо прекращению уголовного дела (уголовного преследования) Европейский Суд определил, что такие решения сами по себе не исключают возможности вывода о чрезмерной продолжительности судебного разбирательства и нарушении требования о разумном сроке уголовного судопроизводства.

Следует отметить, что в ряде случаев правовые позиции, связанные с необходимостью определения срока производств ввиду новых или вновь открывшихся обстоятельств, часто аналогичны соответствующему подходу к необходимости установлению определенного срока содержания под стражей.

Правовой основой для защиты права на разумный срок судебного разбирательства является часть 1 статьи 21 «Достоинство личности охраняется государством» и 46 часть 1 Конституции РФ: «Каждому гарантируется судебная защита его прав и свобод».

Корреспондируют с данной статьей положения Европейской Конвенции о защите прав человека и основных свобод: часть 3 статьи 5 «Право на свободу и личную неприкосновенность» закрепляет право каждого задержанного или заключенного под стражу в соответствии с подпунктом «с» пункта 1 настоящей статьи незамедлительно быть доставленным к судье или к иному должностному лицу, наделенному, согласно закону, судебной властью, и право на судебное разбирательство в течение разумного срока или на освобождение до суда7. Часть 1 статьи 6 «Право на справедливое судебное разбирательство» закрепляет, что каждый в случае спора о его гражданских правах и обязанностях или при предъявлении ему любого уголовного обвинения имеет право на справедливое и публичное разбирательство дела в разумный срок независимым и беспристрастным судом, созданным на основании закона.

Кроме того, содержание права на судебную защиту получило разъяснение в решениях Конституционного Суда РФ: из статьи 46 Конституции во взаимосвязи с ее статьями 19 (часть 1), 47 (часть 1) и 123 (часть 3), устанавливающими принцип равенства всех перед законом и судом, право каждого на рассмотрение его дела в том суде и тем судьей, к подсудности которых оно отнесено законом, и принцип осуществления судопроизводства на основе состязательности и равноправия сторон, следует, что право на судебную защиту - это не только право на обращение в суд, но и возможность получения реальной судебной защиты в форме восстановления нарушенных прав и свобод в соответствии с законодательно закрепленными критериями, которые в нормативной форме (в виде общего правила) предопределяют, в каком суде и в какой процедуре подлежит рассмотрению конкретное дело, что позволяет суду (судье), сторонам, другим участникам процесса, а также иным заинтересованным лицам избежать правовой неопределенности в этом вопросе ${ }^{8}$.

\footnotetext{
${ }^{7}$ Европейская Конвенция о защите прав человека и основных свобод [Электрон.ресурс]. Доступ из справ. - правовой системы «КонсультантПлюс».

8 Постановление Конституционного Суда Российской Федерации от 25 июня 2013 г. №14-П по делу о проверке конституционности положений части 1 статьи 1 , пункта 1 части 1 , частей 6 и 7 статьи 3 Федерального закона «О компенсации за нарушение права на судопроизводство в разумный срок или права на исполнение судебного
} 
Важным моментом является то обстоятельство, что для раскрытия содержания этого права Конституционный Суд Российской Федерации применяет практику Европейского Суда по правам человека: право обратиться в суд с заявлением о присуждении компенсации за нарушение права на судопроизводство в разумный срок другим помимо указанного в статье 6 Конвенции о защите прав человека и основных свобод лица, которому предъявлено обвинение (а в контексте толкования данной статьи Европейским Судом по правам человека - лица, привлекаемого к уголовной ответственности), субъектам уголовного судопроизводства, включая потерпевшего, федеральный законодатель - следуя конституционным принципам равенства всех перед законом и судом, осуществления судопроизводства на основе состязательности и равноправия сторон, реализация которых требует, в свою очередь, соблюдения баланса конституционно значимых интересов при обеспечении в уголовном процессе прав лиц, привлекаемых к уголовной ответственности, и лиц, пострадавших от преступлений, - тем самым расширил для Российской Федерации сферу действия статьи 13 Конвенции о защите прав человека и основных свобод применительно к защите признаваемого ее статьей 6 права на справедливое судебное разбирательство в разумный срок 9 .

Ранее упомянутая нами часть 3 ст. 6.1. Уголовнопроцессуального кодекса Российской Федерации «Разумный срок уголовного судопроизводства» содержит определение периода уголовного судопроизводства, который включает в себя период с момента начала осуществления уголовного преследования до момента прекращения уголовного преследования или вынесения обвинительного приговора ${ }^{10}$. Представляется, что данное определение не соотносится в должной мере с положениями главы 49 Уголовно- процессуального кодекса Российской Федерации «Возобновление производства по уголовному делу ввиду новых или вновь открывшихся обстоятельств»: производство по уголовному делу ввиду новых или вновь открывшихся обстоятельств не является периодом уголовного судопроизводства.

Полагаем, что период уголовного судопроизводства должен включать в себя производство ввиду новых или вновь открывшихся обстоятельств. Нормы Уголовнопроцессуального кодекса Российской Федерации о производстве ввиду новых и вновь открывшихся обстоятельств, имеют правовые лакуны, и хотя содержат положения о

акта в разумный срок», частей первой и четвертой статьи 244.1 и пункта 1 части первой статьи 244.6 Гражданского процессуального кодекса Российской Федерации в связи с жалобой гражданки А.Е. Поповой» [Электрон.ресурс]. Доступ из справ. - правовой системы «КонсультантПлюс».

9 Постановление Конституционного Суда Российской Федерации от 25 июня 2013 г. № 14-П «По делу о проверке конституционности положений части 1 статьи 1 , пункта 1 части 1, частей 6 и 7 статьи 3 Федерального закона «О компенсации за нарушение права на судопроизводство в разумный срок или права на исполнение судебного акта в разумный срок», частей первой и четвертой статьи 244.1 и пункта 1 части первой статьи 244.6 Гражданского процессуального кодекса Российской Федерации в связи с жалобой гражданки А.Е. Поповой» [Электрон.ресурс]. Доступ из справ. - правовой системы «КонсультантПлюс».

10 Уголовно-процессуальный кодекс Российской Федерации от 18.12.2001 г. № 174-Ф3 (ред. от 21.07.2014 г.) [Электрон.ресурс]. Доступ из справ. - правовой системы «КонсультантПлюс». начале сроков возобновления производства (ст. 414), не содержат указания о сроках такого производства. Это означает, что производство может длиться неопределенный период, что может, в ряде случае приводить к необоснованной затяжке производства по уголовному делу.

Указанное выше обстоятельство вступает в противоречие с таким принципом уголовного процесса, как принцип разумности срока уголовного производства. Необходимо ввести данные виды производства по уголовному делу в рамки уголовного производства, применив к нему положения принципа о разумном сроке уголовного судопроизводства. Такой подход подтверждается практикой Конституционного Суда Российской Федерации и Европейского Суда по правам человека.

В целом, правовые позиции, связанные с необходимостью определения срока производств ввиду новых и вновь открывшихся обстоятельств, аналогичны соответствующему подходу к необходимости установлению определенного срока содержания под стражей.

Так, Конституционный Суд РФ подтвердил в п.3 Определения от 04.04.2006 г. N 101-О: «В своих решениях Конституционный Суд Российской Федерации указал на недопустимость избыточного, неограниченного по продолжительности, произвольного и неконтролируемого содержания под стражей, а также на обязанность государства использовать только необходимые и строго обусловленные конституционно оправданными целями меры, связанные с ограничением прав, гарантированных статьей 22 (часть 1) Конституции Российской Федерации и пунктом 3 статьи 14 Международного пакта о гражданских и политических правах ${ }^{11}$.

В то же время как отмечает Конституционный Суд РФ термин «разумный срок» носит оценочный характер, в связи с чем, мера разумной продолжительности не может быть одинаковой для всех дел, т.е. необходимо учитывать фактическую сложность дела, поведение участников процесса, достаточность и эффективность действий суда ${ }^{12}$.

Практика Европейского Суда по правам человека также подтверждает, что сама концепция разумного срока судебного разбирательства предполагает индивидуальный подход.

Европейский Суд по правам человека в Постановлении от 25.11.2003 г. по делу «Шумахер против Люксембурга» рассматривал опрос об оценке длительности периода. Расследование по делу продолжалось девять лет. Европейский Суд, принимая свое Постановление по данному делу, делает ссылку на постановление закрытого заседания исправительного трибунала, которым было установлено, что за последние три года расследования по делу никаких действий властями не

\footnotetext{
${ }^{11}$ Определение Конституционного Суда Российской Федерации от 04.04.2006 г. №101-О «По жалобе гражданина Республики Таджикистан Насруллоева Хабибулло на нарушение его конституционных прав частями первой и второй статьи 466 Уголовно-процессуального кодекса Российской Федерации»// Официальный интернет-портал правовой информации URL:http://pravo.gov.ru (дата обращения 03.10.2014)

12 Постановление Конституционного Суда Российской Федерации от 19 июля 2011 г. № 17-П по делу о проверке конституционности пункта 5 части 1 статьи 244.6 Гражданского процессуального кодекса Российской Федерации в связи с жалобой гражданина С.Ю. Каакуева // Официальный интернет-портал правовой информации URL: http:// pravo.gov.ru (дата обращения 03.10.2014)
} 
DOI: $10.7256 / 1811-9018.2014 .12 .13260$

При цитировании этой статьи сноска на dоі обязательна

\section{Право и политика $12(180) \cdot 2014$}

предпринималось и по делу допущено нарушение требований пункта 1 Статьи 6 Конвенции ${ }^{13}$.

В деле «Александр Новиков против России» Европейский Суд по правам человека рассматривал жалобу на чрезмерную длительность содержания его под стражей (около трех лет) и длительность судебного разбирательства (около трех лет и семи месяцев) по обвинению его в распространении наркотиков и установил, что по делу допущено нарушение требований пункта 3 статьи 5 и пункта 1 статьи 6 Конвенции о защите прав человека и основных свобод ${ }^{14}$.

В деле «Кляхин против России» Европейский Суд по правам человека установил, что период времени, учитываемый при определении продолжительности производства по уголовному делу, начинается в тот день, когда данному лицу «предъявляется обвинение» в самостоятельном и существенном значении этого термина. Суд напоминает, что разумность срока разбирательства надлежит оценивать в свете конкретных обстоятельств дела и с учетом критериев, выработанных судебной практикой, в частности таких, как сложность дела, действия заявителя и действия компетентных властей ${ }^{15}$.

Нарушение п.1 ст.6 Конвенции было установлено Европейским Судом по правам человека и в деле «Никитин против России»: в совокупности, например, с пунктом 2 статьи 4 Протокола № 7 к Конвенции, который прямо позволяет государствам возобновлять производство по делу ввиду открытия новых обстоятельств или в случае, когда обнаружены существенные недостатки, допущенные в ходе предыдущего судебного разбирательства, которые могли повлиять на исход судебного разбирательства. Возможность пересмотра судебного решения или возобновления разбирательства по делу также рассматривалась Комитетом Министров Совета Европы как гарантия восстановления прав, в частности в контексте исполнения постановлений Европейского Суда. В своей Рекомендации № R (2000) 2 о пересмотре и возобновлении судебных разбирательств по ряду дел на национальном уровне после вынесения постановлений Европейским Судом по правам человека Комитет Министров Совета Европы призвал государства-члены Совета Европы к обеспечению того, чтобы национальные правовые системы предусматривали процедуру, в ходе которой дело могло быть пересмотрено или возобновлено. Таким образом, сама возможность возобновления уголовного дела prima facie соответствует требованиям Конвенции, в том числе гарантий ст.6. Однако отдельные конкретные аспекты дела могут выявить, что в

\footnotetext{
${ }^{13}$ Постановление Европейского Суда по правам человека от 25.11.2003 г. по делу «Шумахер (Schumacher)против Люксембурга» (жалоба N 63286/00) [Электрон.ресурс]. Доступ из справ. - правовой системы «КонсультантПлюс».

${ }^{14}$ Постановление Европейского Суда по правам человека от 11.07.2013 г по делу «Александр Новиков (Aleksandr Novikov) против России» (жалоба N 7087/04) [Электрон.ресурс]. Доступ из справ. - правовой системы «КонсультантПлюс».

${ }^{15}$ Постановление Европейского Суда по правам человека по делу «Кляхин против России» (Klyakhin v. Russia). от 30 ноября 2004 г. (жалоба N 46082/99).URL: http://europeancourt.ru/resheniya-evropejskogo-suda-narusskom-yazyke/klyaxin-protiv-rossii-postanovlenie-evropejskogo-suda/ (дата обращения 03.10.2014)
}

действительности то, как это происходит, нарушает саму сущность справедливого судебного разбирательства ${ }^{16}$.

В любом случае, требование разумного срока является императивным, как следует из Постановления Европейского Суда по правам человека по делу «Облов против России»: «Если повторное рассмотрение дела допущено, разбирательство должно быть закончено в пределах «разумного срока», принимая во внимание все относящиеся к делу факторы (см., с необходимыми изменениями, Постановление Европейского Суда от 7 декабря 2006 г. по делу «Иванов против Украины» (Ivanov v. Ukraine), жалоба N 15007/02, § 74; и Постановление Европейского Суда от 2 ноября 2004 г. «Хенуорт против Соединенного Королевства» (Henworth v. United Kingdom), жалоба N 515/02, § 29)» ${ }^{17}$.

В отличие от предложенного ранее авторами ${ }^{18}$ ненормативного «мягкого теста» предлагается применение более приемлемого для уголовного процесса нормативного подхода. С учетом мнения судебных инстанций представляется возможным выделить следующие подходы для разрешения ситуации с неопределенными сроками для разрешения возникшей ситуации:

1. Следует внести изменения в статью 5 УПК РФ, расширив понятие уголовного производства, отнеся к нему наряду с досудебным и судебным производствами производства ввиду новых и вновь открывшихся обстоятельств. Предлагаемая редакция понятия уголовного производства: «уголовное судопроизводство - досудебное и судебное производство по уголовному делу, а также производство ввиду новых или вновь открывшихся обстоятельств».

2. Согласно принципу правовой аналогии, при определении срока во время производства ввиду новых или вновь открывшихся обстоятельств разумно было бы ориентироваться на общий срок производства предварительного следствия (ст. 162 УПК РФ). Началом исчисления такого срока следует считать день возбуждения производства, окончанием - день составления прокурором заключения и направления его с материалами расследования в суд или день вынесения постановления о прекращении производства.

3. В этой связи следует дополнить главу 49 УПК РФ «Возобновление производства по уголовному делу ввиду новых или вновь открывшихся обстоятельств» новой статьей 415.1 «Сроки производства по уголовному делу ввиду новых или вновь открывшихся обстоятельств» (следующей за ст. 415 «Возбуждение производства» и перед ст. 416 «Действия прокурора по окончании провер-

\footnotetext{
${ }^{16}$ Решение Европейского Суда по правам человека «Никитин против России» (Application no. 50178/99) от 20 июля 2004 г.URL: http://www. espch.ru/content/view/31/25/ (дата обращения 03.10.2014)

${ }^{17}$ П. 27 Постановления Европейского Суда по правам человека от 15.01.2009 г. «Дело «Облов (Oblov) против Российской Федерации» (жалоба N 22674/02) // «Бюллетень Европейского Суда по правам человека». - 2009. - № 12.

${ }^{18}$ Герасимова E.B., Косс A.B. Ограничение возможности законного пребывания и проживания в Российской Федерации иностранных граждан: проблемы определения «гуманитарных обстоятельств» в законодательстве и правоприменительной практике// Конституционное и муниципальное право. - 2012. - №12. - С. 28.
} 
DOI: $10.7256 / 1811-9018.2014 .12 .13260$

При цитировании этой статьи сноска на dоі обязательна

Судебная власть

ки или расследования»). Статья, с нашей точки зрения, должна содержать два основных положения:

- к сроку производства ввиду новых или вновь открывшихся обстоятельств применяются положения ст. 162 УПК РФ о сроке предварительного расследования.

- началом исчисления такого срока следует считать день возбуждения производства, окончанием - день составления прокурором заключения и направления его с материалами расследования в суд или день вынесения постановления о прекращении производства.

Введение такого рода изменений в действующий уголовно-процессуальный закон позволило бы совершить очередной важный шаг на пути гармонизации различий в процессуальных подходах на международном и национальном уровнях.

\section{Библиография:}

1. Архив Центрального районного суда г. Калининграда.

2. Определение Конституционного Суда Российской Федерации от 03.04.2014 г. № 687-О «Об отказе в принятии к рассмотрению жалобы гражданина Лунина Валерия Васильевича на нарушение его конституционных прав статьями 1 и 3 Федерального закона «О компенсации за нарушение права на судопроизводство в разумный срок или права на исполнение судебного акта в.4, 244.6 и 244.8 Гражданского процессуального кодекса Российской Федерации». [Электрон.ресурс]. Доступ из справ. - правовой системы «КонсультантПлюс».

3. Определение Верховного Суда Российской Федерации от 11.10.2011 г. № КАС11-528: «При этом суд обоснованно не согласился с доводом заявителя о том, что общая продолжительность судопроизводства по уголовному делу составила 8 лет 5 месяцев, так как в соответствии с нормами процессуального закона, а также Закона о компенсации период судопроизводства в надзорной инстанции не подлежит оценке с точки зрения разумности» [Электрон.ресурс]. Доступ из справ. - правовой системы «КонсультантПлюс».

4. Постановление Пленума Верховного Суда Российской Федерации №30, Пленума Высшего Арбитражного Суда Российской Федерации №64 от 23.12.2010 г. «О некоторых вопросах, возникших при рассмотрении дел о присуждении компенсации за нарушение права на судопроизводство в разумный срок или права на исполнение судебного акта в разумный срок» [Электрон.ресурс]. Доступ из справ. - правовой системы «КонсультантПлюс».

5. Международно-правовые стандарты в уголовной юстиции Российской Федерации: научно-практическое пособие / С.П. Андрусенко, Н.А. Голованова, А.А. Гравина; отв. ред. В.П. Кашепов. М.: Институт законодательства и сравнительного правоведения при Правительстве РФ, Анкил, 2012. - 312 с.

6. Кондрат И.Н. Международные корни уголовно-процессуального принципа «разумный срок уголовного судопроизводства» // Российская юстиция. - 2012. - №12. - С. 29-32.

7. Европейская Конвенция о защите прав человека и основных свобод [Электрон.ресурс]. Доступ из справ. - правовой системы «КонсультантПлюс».

8. Постановление Конституционного Суда Российской Федерации от 25 июня 2013 г. №14-П по делу о проверке конституционности положений части 1 статьи 1 , пункта 1 части 1, частей 6 и 7 статьи 3 Федерального закона «О компенсации за нарушение права на судопроизводство в разумный срок или права на исполнение судебного акта в разумный срок», частей первой и четвертой статьи 244.1 и пункта 1 части первой статьи 244.6 Гражданского процессуального кодекса Российской Федерации в связи с жалобой гражданки А.Е. Поповой» [Электрон.ресурс]. Доступ из справ. - правовой системы «КонсультантПлюс».

9. Уголовно-процессуальный кодекс Российской Федерации от 18.12.2001 № 174-Ф3 (ред. от 21.07. 2014)[Электрон.ресурс]. Доступ из справ. - правовой системы «КонсультантПлюс».

10. Определение Конституционного Суда Российской Федерации от 04.04.2006 г. №101-О «По жалобе гражданина Республики Таджикистан Насруллоева Хабибулло на нарушение его конституционных прав частями первой и второй статьи 466 Уголовно-процессуального кодекса Российской Федерации»// Официальный интернет-портал правовой информации URL:http://pravo.gov.ru (дата обращения 03.10.2014)

11. Постановление Конституционного Суда Российской Федерации от 19 июля 2011 г. № 17-П по делу о проверке конституционности пункта 5 части 1 статьи 244.6 Гражданского процессуального кодекса Российской Федерации в связи с жалобой гражданина С.Ю. Каакуева // Официальный интернет-портал правовой информации URL: http://pravo.gov.ru (дата обращения 03.10.2014)

12. Постановление Европейского Суда по правам человека от 25.11.2003 г. по делу «Шумахер (Schumacher)против Люксембурга» (жалоба N 63286/00) [Электрон.ресурс]. Доступ из справ. - правовой системы «КонсультантПлюс».

13. Постановление Европейского Суда по правам человека от 11.07.2013 г. по делу «Александр Новиков (Aleksandr Novikov) против России» (жалоба N 7087/04) [Электрон.ресурс]. Доступ из справ. - правовой системы «КонсультантПлюс».

14. Постановление Европейского Суда по правам человека по делу «Кляхин против России» (Klyakhin v. Russia). от 30 ноября 2004 г. (жалоба N 46082/99).URL: http://europeancourt.ru/resheniya-evropejskogo-suda-na-russkom-yazyke/klyaxin-protiv-rossii-postanovlenieevropejskogo-suda/ (дата обращения 03.10.2014)

15. Решение Европейского Суда по правам человека «Никитин против России» (Application no. 50178/99) от 20 июля 2004 г.URL: http://www.espch.ru/content/view/31/25/ (дата обращения 03.10.2014)

16. Постановление Европейского Суда по правам человека от 15.01.2009 г. «Дело «Облов (Oblov) против Российской Федерации» (жалоба N 22674/02) // «Бюллетень Европейского Суда по правам человека». - 2009. - № 12.

17. Герасимова Е.В., Косс А.В. Ограничение возможности законного пребывания и проживания в Российской Федерации иностранных граждан: проблемы определения «гуманитарных обстоятельств» в законодательстве и правоприменительной практике// Конституционное и муниципальное право. - 2012. - №12. - С. 24-28.

18. Кузьмина Ю.А. Некоторые особенности практики Европейского Суда в отношении Российской Федерации // NB: Международное право. - 2013. - 3. - С. 68 - 87. DOI: 10.7256/2306-9899.2013.3.2424. URL: http://www.e-notabene.ru/wl/article_2424.html

19. Г. Г. Шинкарецкая Европейский союз и Европейская конвенция о защите прав человека и основных свобод // Международное право и международные организации / International Law and International Organizations. - 2012. - 1. - C. 54 - 64.

20. Агеев В.Н. Правомерность ограничения прав и свобод государственных служащих в Российской Федерации: правовая оценка Конституционного Суда // NB: Вопросы права и политики. - 2013. - 1. - С. 166 - 189. DOI: 10.7256/2305-9699.2013.1.394. URL: http:// www.e-notabene.ru/lr/article_394.html

21. Т.Р. Устов Следственные действия: характерные признаки и особенности обеспечения прав участников при производстве в стадии возбуждения уголовного дела // Право и политика. - 2012. - 12. - С. 2035 - 2043. 
DOI: $10.7256 / 1811-9018.2014 .12 .13260$

При цитировании этой статьи сноска на доі обязательна

\section{Право и политика $12(180) \cdot 2014$}

22. Соловьева Т.В. Об отсутствии единого нормативно закрепленного порядка приведения в исполнение постановлений Европейского Суда по правам человека. // NB: Международное право. - 2013. - 4. - C. 184 - 200. DOI: 10.7256/2306-9899.2013.4.2507. URL: http://www.e-notabene.ru/wl/article_2507.html

\section{References (transliterated):}

1. Kondrat I.N. Mezhdunarodnye korni ugolovno-protsessual'nogo printsipa "razumnyi srok ugolovnogo sudoproizvodstva" // Rossiiskaya yustitsiya. - 2012. - №12. - S. 29-32.

2. Gerasimova E.V., Koss A.V. Ogranichenie vozmozhnosti zakonnogo prebyvaniya i prozhivaniya v Rossiiskoi Federatsii inostrannykh grazhdan: problemy opredeleniya «gumanitarnykh obstoyatel'stv» v zakonodatel'stve i pravoprimenitel'noi praktike// Konstitutsionnoe i munitsipal'noe pravo. - 2012. - №12. - S. 24-28.

3. Kuz'mina Yu.A. Nekotorye osobennosti praktiki Evropeiskogo Suda v otnoshenii Rossiiskoi Federatsii // NB: Mezhdunarodnoe pravo. - 2013. -3. - C. 68 - 87. DOI: 10.7256/2306-9899.2013.3.2424. URL: http://www.e-notabene.ru/wl/article_2424.html

4. G. G. Shinkaretskaya Evropeiskii soyuz i Evropeiskaya konventsiya o zashchite prav cheloveka i osnovnykh svobod // Mezhdunarodnoe pravo i mezhdunarodnye organizatsii / International Law and International Organizations. - 2012. - 1. - C. 54 - 64.

5. Ageev V.N. Pravomernost' ogranicheniya prav i svobod gosudarstvennykh sluzhashchikh v Rossiiskoi Federatsii: pravovaya otsenka Konstitutsionnogo Suda // NB: Voprosy prava i politiki. - 2013. - 1. - C. 166 - 189. DOI: 10.7256/2305-9699.2013.1.394. URL: http://www.enotabene.ru/lr/article_394.html

6. T.R. Ustov Sledstvennye deistviya: kharakternye priznaki i osobennosti obespecheniya prav uchastnikov pri proizvodstve v stadii vozbuzhdeniya ugolovnogo dela // Pravo i politika. - 2012. - 12. - C. 2035 - 2043.

7. Solov'eva T.V. Ob otsutstvii edinogo normativno zakreplennogo poryadka privedeniya v ispolnenie postanovlenii Evropeiskogo Suda po pravam cheloveka. // NB: Mezhdunarodnoe pravo. - 2013. - 4. - C. 184 - 200. DOI: 10.7256/2306-9899.2013.4.2507. URL: http://www.e-notabene.ru/ wl/article_2507.html 